\title{
A guide to Vietnam War resources Government documents, oral histories, antiwar movements
}

$\mathbf{T}$ his past April marked the 40th anniversary of the fall of Saigon to North Vietnamese forces, recognized as the official end of U.S. involvement in the Vietnam War. Despite the passage of time, the legacy of that conflict, which resulted in the deaths of more than 58,000 Americans and possibly millions of Vietnamese, weighs heavily on the present. This has prompted one of the war's leading historians to write: "With the possible exception of the Civil War, no event in U.S. history has demanded more soul-searching than the war in Vietnam." There is little doubt that this anniversary year will spark new research projects on the part of both students and faculty, suggesting the need for librarians to have a readily available resource list.

Over the years, the Vietnam War has been the focus of thousands of books, films, and articles. While there is already an abundance of online resource lists on the topic, the goal of this guide is to emphasize government sources, oral histories, and the increasingly rich array of material concerning the antiwar movement.

\section{Government websites}

- The LBJ Library Reading Room. The Lyndon Baines Johnson Presidential Library has digitized a small number of its 45 million pages that relate to his administration. This digitized content includes Johnson's daily diary, and excerpts from his famous telephone conversations. Two parts of the digital reading room in particular are most interesting to Vietnam researchers. The first is a collection of Johnson's National Security Action Memorandums, which are presidential directives that relate to national security. The second is a collection of contemporary interviews with key Cold War figures-such as Secretary of State Dean Rusk, Foreign Policy Adviser Walt Rostow, and Defense Secretary Robert McNamara-which are helpful to understanding the war from the administration's perspective. Access: http:// www.lbjlibrary.org/research.

- Nixon Presidential Library \& Museum Virtual Library. The website of the Nixon Presidential Library is a good companion site to the Johnson Library, as it includes President Nixon's own daily diary and National Security Action Memorandums. This is augmented by Nixon's speeches, news releases, press conference transcripts, some private memos, and the diary of Nixon aide H. R. Haldeman. The library also places online the full text of the famous Pentagon Papers, which were leaked by Daniel Ellsburg and revealed the United States' covert role in the Vietnam conflict starting in the 1940s. Access: http://nixon.archives.gov/virtuallibrary /documents/index.php.

\section{- Research in Military Records: Vietnam}

War. This site is the National Archives portal to their records on the Vietnam War. Most of the records relate to casualty counts, available for both the United States and Vietnamese. U.S. casualty counts are further broken down by state,

Seth Kershner is public services librarian at Northwestern Connecticut Community College, email: skershner@ nwcc.edu, and Michael Mannheim is collection development librarian at American International College, email: michael.mannheim@aic.edu

๑ 2015 Seth Kershner and Michael Mannheim 
year, branch of service, and other pertinent factors. Files on prisoners of war and soldiers missing in action can also be searched and downloaded in PDF form. When searching, however, users are kicked over to the National Archive's Access to Archival Databases website, where they must redo their search from scratch. $A c$ cess: http://www.archives.gov/research/military /vietnam-war/.

- Vietnam War Commemoration. This website was created by the U.S. Department of Defense as part of a $\$ 15$ million effort to honor veterans and mark the 50 years since U.S. ground troops arrived in Vietnam. Commemorative events are still ongoing, and can be tracked on an interactive map. The site also includes a helpful dose of educational material, including an interactive timeline, printable fact sheets and posters, and links to primary source documents. Readers be warned, however, that the site is not without controversy. According to media reports, the site glosses over some of the war's more notorious incidents and pays little attention to antiwar movements. For example, the timeline does not attach the word massacre to the events at My Lai, and omits John Kerry's testimony at the Fulbright hearings. Access: http://www.vietnamwar50th.com.

\section{U.S. allies}

- Australia and the Vietnam War. Starting in 1962, Australia sent some 60,000 of its military personnel onto the battlefields of Vietnam. This website, created by the Australian Department of Veterans Affairs, seeks to educate readers on Australia's role in the war. The website focuses on battles fought by Australian troops, but also includes detailed sections on how Australia became involved in the war, equipment and weapons, public opinion and the home front, and the eventual pullout of Australian troops after the Tet Offensive. Access: http://vietnam-war. commemoration.gov.au/.

\section{- New Zealand and the Vietnam War.}

New Zealand's own role in the war is remembered here, in the form of photos, audio, video, and memories submitted directly to the site by veterans. Articles cover military operations, the home front and antiwar activities, the home- coming of New Zealand troops, and the aftermath of the war on New Zealand society. There is also a timeline as well as teaching resources. Access: http://www.vietnamwar.govt.nz/.

\section{Primary sources}

- The Avalon Project. A project of the Yale Law School's Lillian Goodman Law Library, The Avalon Project collects primary sources in law, history and diplomacy ranging from 400 B.C.E. to the present day. The section on Indochina spans from 1950 to 1964, ending with President Lyndon Johnson's reaction to the Gulf of Tonkin incident, and thus provides an intriguing narrative of the run up to war told in diplomatic cables, government statements, and presidential addresses. Unfortunately, the documents are provided without any context, making the site difficult to use for less experienced researchers. Access: http://avalon.law. yale.edu/subject_menus/indoch.asp.

- Virtual Vietnam Archive. Texas Tech University's Vietnam Center and Archive is the largest online source for information on the Vietnam War. The archive was formed by Vietnam veterans in 1989 with a mission to "collect and preserve the documentary record of the Vietnam War." The center holds annual guest lectures as well as regular conferences and other events. The digital archive contains more than 550,000 items, and can be searched or browsed. Because of the sheer amount of material available, users are well advised to take advantage of the curated subject guides, with topics ranging from the Tet Offensive and Fall of Saigon to the experiences of Vietnamese Americans. Access: http://www.vietnam.ttu. edu/virtualarchive/.

\section{Veterans issues}

- Vietnam Veterans of America. Founded in 1978, Vietnam Veterans of America (VVA) is a national nonprofit organization designed to promote issues important to veterans, as well as provide outreach and resources to veterans in need. This organization was one of the first to raise national consciousness concerning the plight of returning veterans, many of whom struggled to receive care for post-traumatic 
stress disorder (PTSD) and other health problems related to their service in Vietnam. The VVA website contains information on how veterans can take advantage of benefits, as well as information on PTSD and the risks of exposure to Agent Orange. Those interested in politics can also find information on VVA's legislative action initiatives. Access: http:// vva.org/.

- Vietnam Veterans Memorial Fund. This site contains more information than the site of the National Park Service, which is centered on visiting the memorial in Washington D.C. Visitors to this site may scroll through or search an interactive wall of faces, each one linking to the profile of one of 58,307 (as of May 2015) fallen soldiers whose names are ascribed on the wall. Visitors may also take a virtual tour of the Education Center and download teaching and learning resources on the Vietnam War. Access: http://www.vvmf.org/.

\section{Oral histories}

- The Rutgers Oral History Archives. Calling itself the "\#15 oral history site in the world," this site is contributed to by Rutgers graduates who served in Vietnam. All four branches of the military are presented, and interviews may be downloaded in HTML or PDF format. Access: http://oralhistory. rutgers.edu/military-history/29-conflict-index /170-vietnam-war-indexv.

- Veterans History Project. A project of the Library of Congress (LC) American Folklife Center, the project "collects first-hand accounts of U.S. veterans" ranging from World War I through the post-9/11 conflicts in Iraq and Afghanistan. One of LC's most reliable partners since this crowdsourced project has been public libraries, which often coordinate local projects and provide space for interviews. Thousands of these interviews have been digitized, an online search tool allows users to filter search results by the interviewee's gender, branch of service, and even whether the veteran spent time as a prisoner of war. Access: http://www.loc.gov/vets/.

- Vietnam Era Oral History Project.

A project of Utah Valley University, this site contains 20 interviews with Vietnam veterans. Most of the interviews were conducted in 2010. Although the interviews were videotaped, only excerpts are provided, but full interviews are available in audio and transcript form. Access: http://contentdm.uvu.edu/cdm /search/collection/Vietnam.

\section{The Antiwar Movement}

- Antiwar and Radical History Project.

From the University of Washington, this site seeks to provide an overview of antiwar activities from around the Pacific Northwest. In doing so, the site gives us a history from World War I to the present. The section on the Vietnam War is further broken down into four sections: student activism, draft resistance, scanned photos and documents, and antiwar voices from within the military. Access: https:// depts.washington.edu/antiwar/.

- FBI Files on the Antiwar Movement. During the Vietnam War, the Federal Bureau of Investigation (FBI) acted as a kind of secret police: spying on antiwar activists and other dissidents, compiling dossiers, and engaging in what some might call "dirty tricks" to disrupt their organizations. Today the FBI's website makes some of its investigative files from that era available to the public, including thousands of pages relating to the antiwar movement. Here users can search subcollections of files on famous personalities (such as historian Howard Zinn) and prominent antiwar organizations (like the Quaker-based American Friends Service Committee). Depending on the browser being used, some of the e-readers on this website will be nonfunctioning and require users to download the PDF version. Access: https://vault.fbi.gov/antiwar-movement.

- FBI Files on Vietnam Veterans Against the War. Vietnam Veterans Against the War (VVAW) was founded in 1967 and quickly became one of the most visible antiwar groups of the 1960s and 1970s. This archive, containing 21,477 pages of documents received in response to VVAW's Freedom of Information Act requests, chronicles the group's organizing activities across the country. (Fully searchable versions of these documents are available to 
subscribers of Gale's Archives Unbound database). Access: http://www.wintersoldier.com/ index.php?topic $=$ VVAWFBI.

- Oral History of Utah Peace Activists. Another Utah Valley University Project, this site focuses on local peace activists and features transcripts and audio interviews with a wide range of activists, including military veterans who turned against the war and longtime peace activists. Access: http://www.uvu.edu /library/archives/peace.html.

- The Pacifica Radio/UC Berkeley Social Activism Sound Recording Project. UCBerkeley was a hotbed of student activism during the Vietnam era, and Pacifica Radio reporters covered most of the major events of that time. This website provides a timeline of antiwar actions in California with links to audio, video, and primary sources such as newspaper articles. While the timeline is extensive, unfortunately many of the links require UC library access, and the age of the site (it was first created in the 1990s) means the audio clips are short and of low quality. Access: http://www.lib.berkeley.edu/MRC /pacificaviet.html.

- Vietnam War Ephemera Collection. Part of the University of Washington Libraries' digital collections, this site collects leaflets and newspapers that were distributed on campus by the Students for a Democratic Society in the 1960s and 1970s. Users may search through a large collection of scanned documents related to the antiwar movement, as well as other hot social issues of the time. All of the scans are high-quality. Access: http://content.lib. washington.edu/protestsweb/.

\section{Miscellaneous}

- Antiwar Movement Curriculum, Stanford History Education Group. A recent survey of 13 commonly used high school and college history textbooks showed that only one provides an in-depth treatment of the Vietnam antiwar movement. ${ }^{2}$ Teaching faculty who want to make up for those deficiencies or move away from textbooks entirely will appreciate what the Stanford History Education Group (SHEG) is doing. As a partner with the Library of Congress's Teaching with Primary Sources Program, SHEG advocates the use of primary source documents in the $\mathrm{K}-12$ classroom in an effort to help students "read like an historian." This site lets registered users download online curricula, including a unit on the Vietnam Antiwar Movement that includes a lesson plan, original documents, and a graphic organizer. Registration is free. Access: http://sheg.stanford.edu/anti-vietnam -war-movement.

- King and Vietnam Curriculum. Stanford University is also home to the Martin Luther King, Jr. Research and Education Institute. King began to speak out against U.S. involvement in Indochina beginning in 1965 and most forcefully after his speech at New York's Riverside Church in April 1967. In addition to compiling the King Papers, maintaining an online encyclopedia, and many other valuable services, the King Institute provides curriculum to teach about King's opposition to the Vietnam War. Access: https://kinginstitute. stanford.edu/liberation-curriculum/create -your-own-classroom-activity/king-and -vietnam.

- Vietnam War Bibliography. A compilation of hundreds of books, articles, and dissertations by Edwin Moise, professor of history at Clemson University. France has a long history of involvement in Vietnam, and some researchers will surely appreciate the inclusion on this list of several Frenchlanguage sources. While its length and layout make this bibliography appear daunting at first, very specific categories help the user find materials on their topic. Another helpful feature-many entries are also annotated. Access: http://www.clemson.edu/caah/history /FacultyPages/EdMoise/bibliography.html.

\section{Notes}

1. Christian Appy, American Reckoning: The Vietnam War and our National Identity (New York: Viking, 2015), xii.

2. Penny Lewis, Hardhats, Hippies, and Hawks: The Vietnam Antiwar Movement as Myth and Memory (Ithaca, NY: Cornell University Press, 2013), 41 ff. 工 